\title{
Alterations with age in peripheral blood lymphocyte subpopulations and cytokine synthesis in beagles
}

This article was published in the following Dove Press journal:

Veterinary Medicine: Research and Reports

24 August 2012

Number of times this article has been viewed

\author{
Megumi Fujiwara ${ }^{1,2}$ \\ Tomohiro Yonezawa ${ }^{3}$ \\ Toshiro Arail \\ Ichiro Yamamoto' \\ Hiromichi Ohtsuka ${ }^{2}$ \\ 'Laboratory of Veterinary \\ Biochemistry, Nippon Veterinary and \\ Life Science University, Tokyo, Japan; \\ ${ }^{2}$ Laboratory of Large Animal Internal \\ Medicine, ${ }^{3}$ Laboratory of Veterinary \\ Physiology, Kitasato University, \\ Towada, Japan
}

Purpose: The immune system is considered to be affected by aging, which is linked to various immune pathogeneses. The purpose of this study was to determine age-associated changes in immune function of healthy dogs (beagles), specifically those of naive and memory $\mathrm{T}$ lymphocytes, based on cytokine synthesis.

Patients and methods: Blood samples were obtained from 44 healthy beagles that were divided into three age-groups: young ( $<4$ years), middle-aged ( $4-8$ years), and older dogs ( $>8$ years). Subpopulations of T lymphocytes were determined by flow cytometry. Transcriptional (mRNA) levels of cytokines were determined for primary-cultured leukocytes using quantitative real-time polymerase chain reaction.

Results: There were negative correlations between dogs' ages and the number of peripheral blood mononuclear cells, $\mathrm{T}$ cells, and $\mathrm{B}$ cells. In particular, the number of naive $\mathrm{CD}^{+} \mathrm{CD}^{2} 5 \mathrm{RA}^{+}$ $\mathrm{T}$ cells and $\mathrm{CD} 8^{+} \mathrm{CD} 45 \mathrm{RA}^{+} \mathrm{T}$ cells significantly decreased with age. The mRNA levels for interleukin (IL)-2, IL-2R $\alpha$, and interferon-gamma were significantly higher in young or middleaged dogs $(P<0.05)$, whereas IL-4 mRNA expression was not significantly different over the different age-groups. IL-2R $\gamma$ mRNA expression tended to decrease with age.

Conclusion: Decreases of naive $\mathrm{CD}^{+}$and naive $\mathrm{CD}^{+} \mathrm{T}$ cells may be related to age-related immunosenescence in dogs. With regard to cytokine production, leukocyte IL-4 and IL-10 mRNA levels did not change with age, whereas IL-2, IL-2R $\alpha$, and IL-2R $\gamma$ mRNA levels decreased with age. These altered cytokine mRNA expression patterns may contribute to decreased naive T-cell function(s) with aging.

Keywords: aging, leukocyte subpopulation, cytokine, dog, naive T cell, IL-2R

\section{Introduction}

The occurrence of age-related disorders, such as tumors in $\operatorname{dogs}^{1}$ and renal inflammation in cats, ${ }^{2}$ increases with extended life span. The immune system is considered to be affected by aging, which is linked to various immune pathogeneses. ${ }^{3,4}$ The following age-related immunosenescent changes have been reported for dogs: reduced proliferative responses of peripheral blood mononuclear cells (PBMCs), ${ }^{5-7}$ reduced major histocompatibility complex (MHC) class II expression by peripheral blood lymphocytes $;{ }^{8}$ reduced numbers of peripheral blood T and B cells; ${ }^{9,10}$ reduced numbers of $\mathrm{CD}^{+} \mathrm{T}$ cells; ${ }^{1,11}$ and reduced CD4/8 T-cell ratios. ${ }^{8,12-14}$ Moreover, compared with young dogs, aged dogs have reduced numbers of circulating naive $T$ cells and increased numbers of memory T cells. ${ }^{15}$ Naive T cells are important to mount an immune response to various newly encountered antigens; naive $\mathrm{CD}^{+}$and $\mathrm{CD} 8^{+} \mathrm{T}$ cells, in particular, are important for defenses against externally derived (bacteria, viruses) and internally derived (neoplastic cells) antigenic challenges, respectively.
Correspondence: Hiromichi Ohtsuka Veterinary Internal Medicine, School of Veterinary Medicine, Kitasato University, Towada, Aomori 034-8628, Japan

$\mathrm{Tel}+8|\mathbf{I} 17623437|$

Fax +81176238703

Email otsuka@vmas.kitasato-u.ac.jp 
To assess the basic immune functions of $\mathrm{T}$ cells, it is useful to determine their cytokine synthesis capability. $\mathrm{CD}^{+} \mathrm{T}$ cells are divided into two distinct subsets based on their cytokine production patterns: type 1 (Th1) and type 2 (Th2). Th1 cytokines, such as interleukin (IL)-2 and interferon (IFN) $-\gamma$, are required for the generation of cytotoxic $T$ cells and the activation of natural killer cells. IL-2 produced by activated $\mathrm{T}$ cells promotes the proliferation, differentiation, and survival of mature $\mathrm{T}$ and B cells. ${ }^{16}$

We investigated the mRNA expressions of Th1 and Th2 cytokines and the IL-2 receptor (IL-2R) in peripheral blood leukocytes of dogs (beagles) as a function of age. Our purpose was to determine if there were age-associated changes in immune functions in dogs, specifically those of naive and memory $\mathrm{T}$ lymphocytes, based on cytokine synthesis.

\section{Materials and methods}

\section{Animals}

Normal healthy beagles $(n=44)$ were used for this study. All dogs had been referred to the veterinary teaching hospitals of Kitasato University during 2007-2008. Dogs were divided into three age-groups, as in a previous report: ${ }^{17}$ young ( $1-3$ years old; $n=18$ ); middle-aged ( $4-7$ years old; $n=13$ ); and older dogs $(8-12$ years old; $\mathrm{n}=13)$. A body-condition score (BCS) was assessed and expressed on a five-point scale: 1, thin; 2, lean; 3, optimal; 4, obese, 5, gross, as described by Laflamme. ${ }^{18}$ This study followed the Guidelines for Institutional Laboratory Animal Care and Use of the School of Veterinary Medicine of Kitasato University.

\section{Biochemical and hormonal analysis of blood}

Peripheral blood was collected from a cervical vein into sodium fluoride-coated tubes without an anticoagulant. To obtain serum, a sample was centrifuged at $1500 \mathrm{~g}$ for 10 minutes. Biochemical analyses of these samples used an AU400 Clinical Chemistry Analyzer (Olympus, Tokyo, Japan).

\section{Classification of canine peripheral blood mononuclear cells}

Peripheral blood from a cervical vein was collected into EDTA tubes. PBMCs were isolated by gradient centrifugation at $750 \mathrm{~g}$ for 60 minutes using Lymphoprep (Axis-Shield, Oslo, Norway; specific gravity $=1.077 \pm 0.001)$. Cells were washed twice with phosphate-buffered saline (PBS). Lymphocytes were labeled with CD molecules by incubating cells with anti-mouse immunoglobulin (Ig)G antibodies (CD4, CD8, CD21, MHC, CD45R, and CD14; Serotec, Kidlington, UK;
VMRD, Pullman, WA; Beckman Coulter, Fullerton, CA) for 60 minutes at $4^{\circ} \mathrm{C}$. The cells were then washed and incubated with anti-mouse IgG antibodies labeled with phycoerythrin or fluorescein isothiocyanate for 30 minutes at $4^{\circ} \mathrm{C}$. Cells were washed with PBS, and CD antigen expressions were analyzed using a FACScan flow cytometer (Becton Dickinson, Mountain View, CA). The CellQuest software package (BD, Franklin Lakes, NJ) was used for data acquisition and analysis. Absolute counts for lymphocyte subsets were determined by: (lymphocyte absolute counts $\times$ percentage of fluorescent positive cells within lymphogate)/100.

\section{Primary culture of PBMCs}

Peripheral blood from a cervical vein was collected into heparin tubes, and PBMCs were prepared using Lymphoprep. These cells were cultured at a density of $5 \times 10^{6}$ cells $/ \mathrm{mL}$ in Roswell Park Memorial Institute 1640 culture medium supplemented with $10 \%$ fetal calf serum at $37^{\circ} \mathrm{C}$ in $5 \% \mathrm{CO}_{2}$ for 12 hours with or without stimulation of PBMC. After culture, canine cells were harvested by centrifugation and total RNA was extracted using TRIzol (Invitrogen, Carlsbad, CA).

\section{RNA purification}

RNA purification, reverse transcription, and mRNA expression were examined according to the manufacturer's instructions. Briefly, after the addition of $0.2 \mathrm{~mL}$ of chloroform and thorough mixing, an RNA solution in TRIzol was incubated on ice for 5 minutes. Then, the sample was centrifuged at $7500 \mathrm{~g}$ for 15 minutes at $4^{\circ} \mathrm{C}$. After the addition of $0.2 \mathrm{~mL}$ of isopropanol to the separated aqueous layer, the sample was incubated on ice for 15 minutes. After centrifugation at $7500 \mathrm{~g}$ for 15 minutes at $4^{\circ} \mathrm{C}$, the supernatant was removed, $70 \%$ ethanol was added, and it was dried. Finally, total RNA was dissolved in $20 \mu \mathrm{L}$ of nuclease-free water. RNA concentration was determined with a Nano Drop ND-1000 Spectrophotometer (LMS, Tokyo, Japan). cDNA synthesis used $1 \mu \mathrm{g}$ of RNA, adjusted to $10 \mu \mathrm{L}$ with nuclease-free water, which was reverse-transcribed with oligo dT primers. After incubation at $68^{\circ} \mathrm{C}$ for 5 minutes, the sample was added to a mixed liquor containing $5 \times$ first-strand buffer $(4 \mu \mathrm{L}), 10 \mathrm{mM}$ dNTP mix $(1 \mu \mathrm{L}), 25 \mathrm{mM} \mathrm{MgCl}_{2}$ solution $(2 \mu \mathrm{L}), 0.1 \mathrm{M}$ DTT $(2 \mu \mathrm{L})$, and Superscript II RNaseH Reverse Transcriptase $(0.7 \mu \mathrm{L})$ (Invitrogen, Carlsbad, CA). This sample was first incubated at $42^{\circ} \mathrm{C}$ for 50 minutes and then at $68^{\circ} \mathrm{C}$ for 15 minutes.

\section{Real-time PCR analysis}

Quantification of mRNA used real-time polymerase chain reaction $(\mathrm{PCR})$ analysis. The sequences for canine IL-2, 
IFN- $\gamma$, IL-4, IL-10, IL-2 receptors (IL-2R $\alpha$ and IL-2R $\gamma$ ), and glyceraldehyde-3-phosphate dehydrogenase (GAPDH) mRNA were obtained from GenBank. Our designed primers were; IFN- $\gamma$ : 5'-CCAGATGTATCGGAGCGGTGG TTATCGCCTTGCGCTGGACC-3', IL-2: 5'-GCAT CGCACTGACGCTTGTA TTGCTCCATCTGTTGCTCTGTT-3', IL-2R $\gamma$ 5'-CAAGAGCATCTGCAAAACCA GCTTGCTTGAAGCTCTTCGT-3', IL-2R $\gamma:$ 5'-CCCC ATGT TACACC C TA A ACC TGA A AGT T TCCGGGCCCTCACATTG-3', IL-4: 5'-ATGGGTCTC ACCTCCCAACTG TCAATGCCTGTAGTATTTCTTC-3', IL-10: 5'-TACCTGGGTTGCCAAGCCCT TTCACAGAGAAGCTCAGTAAAT-3', GAPDH: 5'-GGGGCCATCCACAGTCTTCT GCCAAAAGGGTCATCATCTC-3'. Mixed solutions of primers and SYBR Green PCR Master Mix (PE Applied Biosystems, Foster City, CA) used a 7700 Sequence Detector (PE Applied Biosystems) with denaturing at $50^{\circ} \mathrm{C}$ for 30 minutes and $95^{\circ} \mathrm{C}$ for 10 minutes, followed by 45 cycles at $95^{\circ} \mathrm{C}$ for 15 seconds and $60^{\circ} \mathrm{C}$ for 1 minute. The target gene expression was normalized against endogenous GAPDH giving a $\triangle \mathrm{CT}$ value and calibrated with the $\triangle \mathrm{CT}$ value from the sample with lowest expression giving a $\Delta \Delta \mathrm{CT}$. Relative expression values were transfrmed from logarithmic to linear form putting $\Delta \Delta \mathrm{CT}$ into the equation $2^{-\Delta \Delta \mathrm{CT}}$.

\section{Statistical analysis}

Results are given as mean \pm standard error. Relationships between dogs' age and peripheral blood leukocyte subpopulations were assessed using Spearman's rank-order correlation coefficients. Statistical analysis using the group comparisons was done by Student's $t$-test or one-way analysis of variance using GraphPad Prism software (GraphPad, San Diego, CA). $P$-values of $<0.05$ were considered significant.

\section{Results}

For this study, blood samples were obtained from healthy beagles of various ages. These were divided into three groups based on age: young ( $1-3$ years old; $n=18)$; middle-aged (4-7 years old; $\mathrm{n}=13)$; and older dogs $(8-12$ years old; $\mathrm{n}=13$ ). Their BCSs ranged from 2.5 to 4.0. There was no significant correlation between age and BCS (Table 1). There were no significant differences in white blood cell and red blood cell counts, except for mean corpuscular volume: middle-aged dogs had greater mean corpuscular volume values than dogs in the other age-groups $(P<0.05$; Table 1).
Table I Clinical characteristics of dogs

\begin{tabular}{lccc}
\hline Variable & \multicolumn{1}{l}{$\begin{array}{l}\text { Young } \\
(18)\end{array}$} & $\begin{array}{l}\text { Middle-aged } \\
(13)\end{array}$ & \multicolumn{1}{l}{$\begin{array}{l}\text { Aged } \\
(13)\end{array}$} \\
\hline BCS & $3.13 \pm 0.09$ & $2.96 \pm 0.09$ & $3.17 \pm 0.17$ \\
Age (years) & $1.72 \pm 0.14^{\mathrm{a}}$ & $5.02 \pm 0.23^{\mathrm{b}}$ & $10.24 \pm 0.52^{\mathrm{c}}$ \\
$\mathrm{WBC}\left(\times 10^{2} / \mathrm{mL}\right)$ & $139.39 \pm 10.24$ & $129.69 \pm 12.16$ & $113.23 \pm 7.94$ \\
$\mathrm{RBC}\left(\times 10^{4} / \mathrm{mL}\right)$ & $690.00 \pm 30.20$ & $705.15 \pm 34.7 \mathrm{I}$ & $637.54 \pm 12.66$ \\
$\mathrm{Hb}(\mathrm{g} / \mathrm{dL})$ & $15.94 \pm 0.70$ & $16.61 \pm 0.84$ & $14.92 \pm 0.3 \mathrm{I}$ \\
$\mathrm{Ht}(\%)$ & $45.17 \pm 1.97$ & $47.82 \pm 2.35$ & $42.05 \pm 0.76$ \\
$\mathrm{MCV}(\mathrm{fl})$ & $65.56 \pm 0.63^{\mathrm{a}}$ & $67.84 \pm 0.62^{\mathrm{b}}$ & $66.02 \pm 0.58^{\mathrm{a}}$ \\
$\mathrm{MCH}(\mathrm{Pg})$ & $23.12 \pm 0.25$ & $23.55 \pm 0.29$ & $23.42 \pm 0.30$ \\
$\mathrm{MCHC}(\mathrm{g} / \mathrm{dL})$ & $35.28 \pm 0.17$ & $34.70 \pm 0.19$ & $35.48 \pm 0.25$ \\
$\mathrm{PLT}\left(\times 10^{4} / \mathrm{mL}\right)$ & $21.22 \pm 2.45$ & $16.69 \pm 2.42$ & $19.08 \pm 1.92$ \\
\hline
\end{tabular}

Notes: Values are represented as mean \pm standard deviation; different letters, a, b, $\mathrm{c}$ indicate statistically significant differences between groups $(P<0.05)$.

To determine if there were alterations with age in peripheral blood leukocyte subpopulations in dogs, lymphocyte subsets were evaluated using a flow cytometric immunophenotyping method. Representative subpopulations are shown in the scatter diagrams (Figure 1). There were significant negative correlations between dogs' ages and the number of PBMCs, $\mathrm{CD}^{+} \mathrm{T}$ cells, CD4 ${ }^{+} \mathrm{T}$ cells, $\mathrm{CD}^{+} \mathrm{T}$ cells, and $\mathrm{CD} 21^{+} \mathrm{B}$ cells. Notably, the number of $\mathrm{CD} 4{ }^{+} \mathrm{CD} 45 \mathrm{R}^{+} \mathrm{T}$ cells (naive helper T cells) and $\mathrm{CD} 8^{+} \mathrm{CD} 45 \mathrm{R}^{+} \mathrm{T}$ cells (naive killer $\mathrm{T}$ cells) decreased significantly with age. The numbers of CD45R- $\mathrm{T}$ cells (memory $\mathrm{T}$ cells) did not change with age for either $\mathrm{CD}^{+}$or $\mathrm{CD} 8^{+} \mathrm{T}$ cells.

The mRNA levels for various cytokines in cultured PBMCs were analyzed using quantitative real-time PCR (Figure 2). Leukocytes were cultured for 12 hours under optimized conditions. mRNA levels for IL-2 and IL-2R $\alpha$ were significantly increased only in the young and middleaged groups, respectively. IL-2R $\gamma$ mRNA expression tended to decline with age. By comparison, IL-4 and IL-10 mRNA expressions did not change with age.

\section{Discussion}

In the present study, no changes were found in the clinical conditions and the biochemical examinations of healthy beagles in different age-groups. However, for peripheral blood leukocyte subpopulations, there were significant negative correlations between the numbers of PBMCs, $\mathrm{CD}^{+}$ $\mathrm{T}$ cells, $\mathrm{CD} 8^{+} \mathrm{T}$ cells, $\mathrm{CD} 4^{+} \mathrm{CD} 45 \mathrm{R}^{+} \mathrm{T}$ cells (possibly naive cells), $\mathrm{CD} 8^{+} \mathrm{CD} 45 \mathrm{R}^{+} \mathrm{T}$ cells, $\mathrm{CD} 21^{+} \mathrm{B}$ cells and dogs' ages. In contrast, there were no significant correlations between the numbers of $\mathrm{CD}^{+} \mathrm{CD} 45 \mathrm{R}^{-} \mathrm{T}$ cells (possibly memory cells) and $\mathrm{CD}^{+} \mathrm{CD} 45 \mathrm{R}^{-} \mathrm{T}$ cells and dogs' ages. Thus, the subpopulations that were reduced in older healthy dogs were characteristically naive $\mathrm{T}$ cells. These results are in agreement 

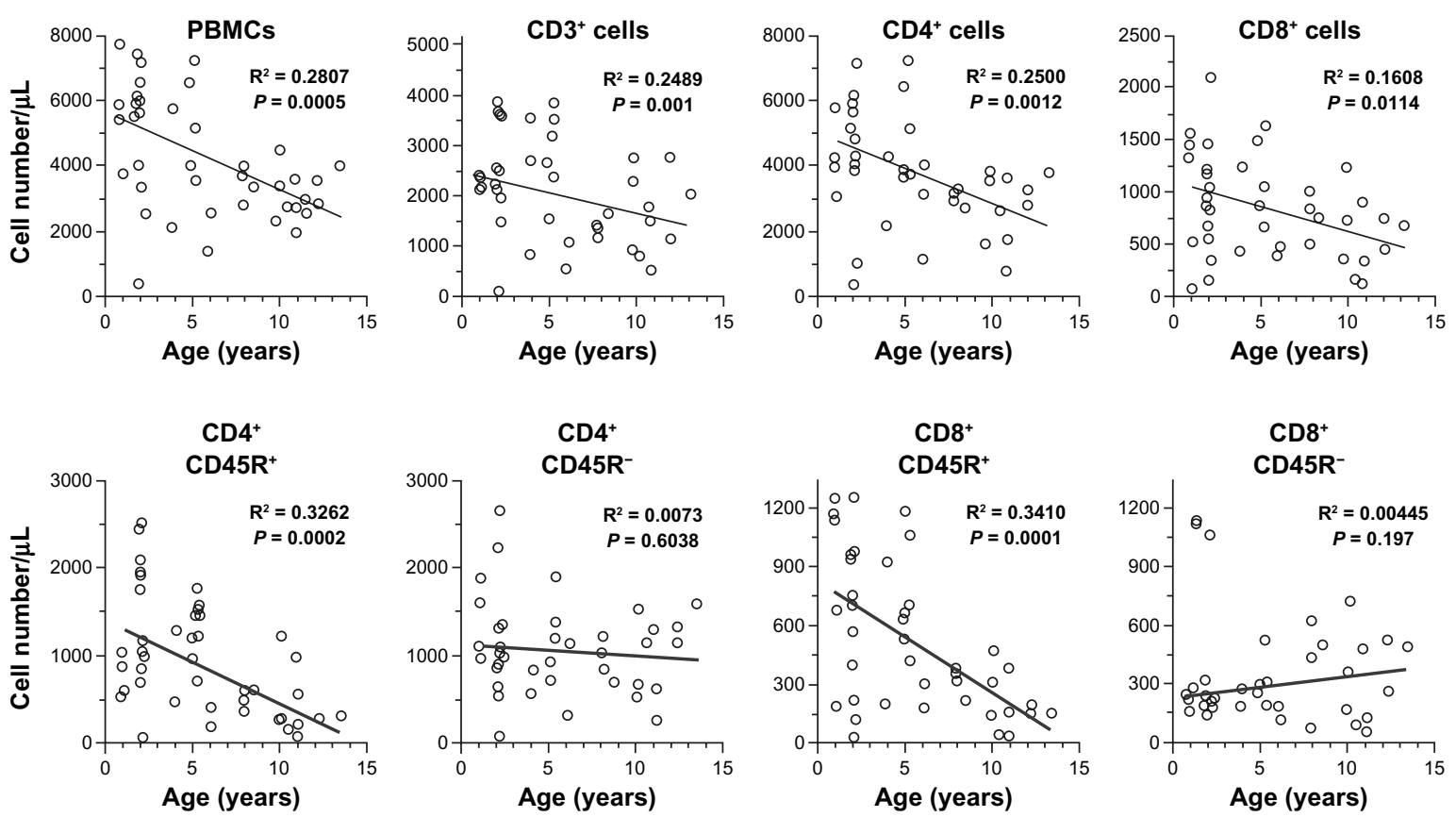

Figure I Scatter diagrams for age-related changes in peripheral blood leukocyte subpopulation in beagles.

Notes: Numbers of peripheral blood mononuclear cells (PBMCs), CD3 ${ }^{+} T$ cells, $C D 4^{+} T$ cells, $C D 8^{+} T$ cells and $C D 45 R^{+-}$cells, $C D 4^{+}$or $C D 8^{+} T$ cells versus age in individual dogs are shown by open circles $(n=44)$. All of these variables, except for $C D 4^{+} C D 45 R^{-} T$ cells and $C D 8^{+} C D 45^{-} T$ cells, were significantly negatively correlated with dogs' age $(P<0.05)$.

with human studies. ${ }^{19,20}$ Thus, the decrease in naive T cells may contribute to reduced T-cell responses to newly encountered antigens in aged dogs, as is observed in humans. ${ }^{21}$

In this study, the IL- 2 and IFN- $\gamma$ mRNA levels in Con A-stimulated PBMCs were significantly increased in cells from young and middle-aged dogs, respectively. In rats, naive T cells are the best IL- 2 producers. ${ }^{22}$ IFN- $\gamma$ is also primarily produced by naive but not memory $\mathrm{T}$ cells. ${ }^{23}$ Therefore, the age-related reductions of IL- 2 and IFN- $\gamma$ mRNA expressions may be due to the reduced numbers of naive $\mathrm{T}$ cells in older dogs. In contrast, IL-4 and IL-10 mRNA expressions appeared not to change with age. Memory $\mathrm{T}$
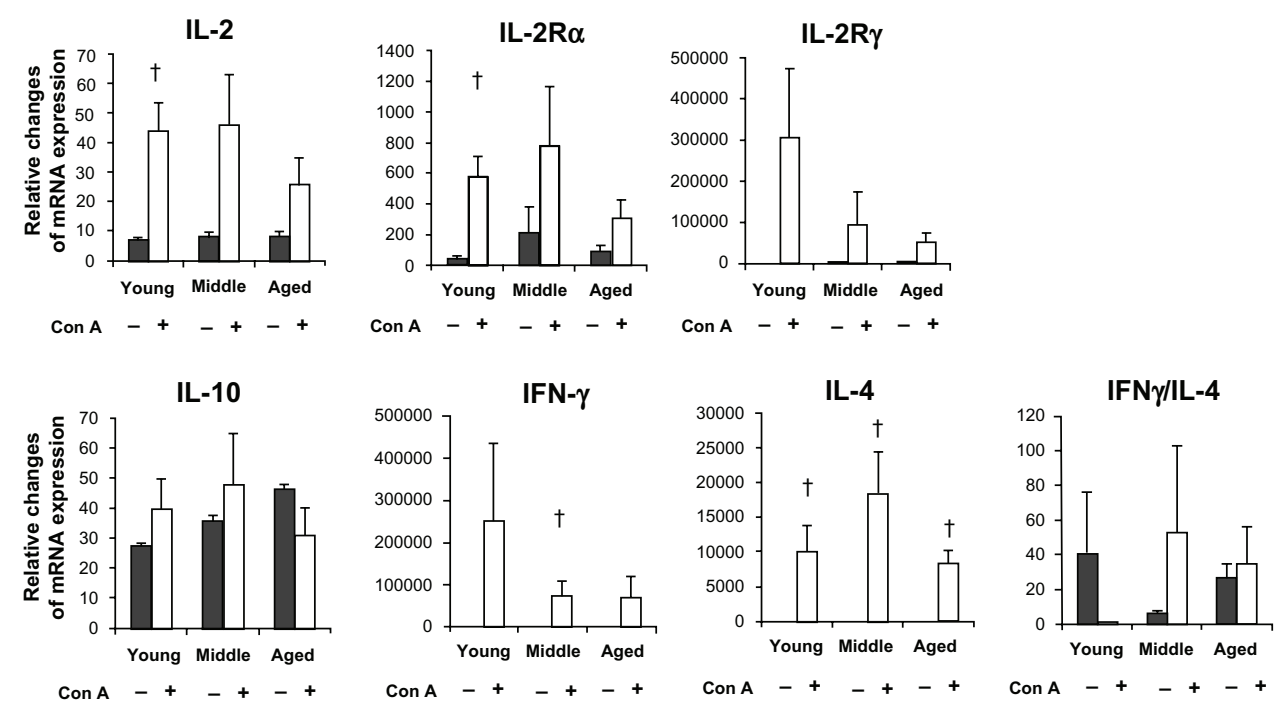

Figure 2 Age-related changes in the transcriptional (mRNA) levels for IL-2, IL-2R $\alpha$, IL-2R $\gamma$, IL-I0, IFN $\gamma$, IL-4, and IFN $\gamma /$ IL-4. mRNA levels were determined I2 hours after stimulation of PBMCs with Con A.

Notes: The control mRNA levels (gray bars) and mRNA levels induced by con-A stimulation (open bars) in PBMCs are shown in each age-group. IL-2, IL-2R $\alpha$, and IFN $\gamma$ mRNA levels were significantly increased only in young or middle-aged dogs $(P<0.05)$. IL-4 mRNA expression was significantly increased in all age-groups after Con-A stimulation $(P<0.05)$.

Abbreviations: IL, interleukin; PBMCs, peripheral blood mononuclear cells; IFN, interferon. 
cells can produce significant amounts of IL- $4 .{ }^{23}$ Thus, it is possible that memory T cells, which did not change with age, may be primarily related to age-independent IL-4 mRNA expression.

Age-associated alterations in IL-2R mRNA expression will require further investigation. In this study, IL-2R $\gamma$ mRNA expression tended to be downregulated with dogs' age. IL-2R $\gamma$-related cytokines appear to be essential for naive cell survival through the maintenance of antiapoptotic pathways. ${ }^{24,25}$ These changes in IL-2R $\gamma$ mRNA patterns may also contribute to the decreases in naive T-cell functions observed with aging. In addition, IL-2R $\alpha$ mRNA expression decreased in an age-dependent manner. IL-2R $\alpha$ can effectively increase the formation of ternary complexes. ${ }^{26}$ Because IL-2R $\alpha$ transmits much stronger proliferative and differentiation signals, age-related decreases in these IL-2R mRNA expressions may play an essential role in the decline of naive $\mathrm{T}$ cells.

The decline in immune function in older animals may be related to an increased incidence of certain diseases. However, a direct association between a decline in immune function and an increased susceptibility to diseases has not been reported. From the results of this study, the age-related decreases in naive T cells and IL-2R mRNA expression may contribute to the decline in immune function. Further studies will be necessary to determine whether these results are directly linked to clinical problems.

\section{Conclusion}

In summary, we analyzed the relationship between peripheral blood leukocyte subpopulations and their cytokine synthesis and age in healthy dogs. First, the numbers of naive $\mathrm{T}$ cells decreased with age, which may contribute to the reduced cytokine production by these cells. Second, the IL-2R $\alpha$ and IL-2R $\gamma$ mRNA expression levels in PBMCs decreased with age. These reduced mRNA expressions may contribute to the decline in naive $T$ cells. Reduced numbers of naive T cells and IL-2R mRNA expression could affect each other and be related to immunosenescence associated with aging.

\section{Acknowledgments}

We thank Drs Hori Yasutomo and Okano Shozo for their help with animal care.

\section{Disclosure}

This work was supported by the Japan Pet Nutrition Society. The authors declare no conflicts of interest in this work.

\section{References}

1. Watabe A, Fukumoto S, Komatsu T, Endo Y, Kadosawa T. Alterations of lymphocyte subpopulations in healthy dogs with aging and in dogs with cancer. Vet Immunol Immunopathol. 2011;42:189-200.

2. Lawler DF, Evans RH, Chase K, et al. The aging feline kidney: a model mortality antagonist? J Feline Med Surg. 2006;8:363-371.

3. Finch EC. Longevity, Senescence and the Genome. Chicago: University of Chicago Press; 1994:922.

4. Rose MR. Evolutionary Biology of Ageing. New York: Oxford University Press; 1991.

5. Greeley EH, Kealy RD, Ballam JM, Lawler DF, Segre M. The influence of age on the canine immune system. Vet Immunol Immunopathol. 1996;55:1-10.

6. Greeley EH, Ballam JM, Harrison JM, Kealy RD, Lawler DF, Segre M. The influence of age and gender on the immune system: a longitudinal study in Labrador retriever dogs. Vet Immunol Immunopathol. 2001;82:57-71.

7. Greeley EH, Spitznagel E, Lawler DF, Kealy RD, Segre M. Modulation of canine immunosenescence by life-long caloric restriction. Vet Immunol Immunopathol. 2006;111:287-299.

8. HogenEsch H, Thompson S, Dunham A, Ceddia M, Hayek M. Effect of age on immune parameters and the immune response of dogs to vaccines: a cross-sectional study. Vet Immunol Immunopathol. 2004;97:77-85.

9. Strasser A, Teltscher A, May B, Sanders C, Niedermüller H. Age-associated changes in the immune system of German shepherd dogs. J Vet Med A Physiol Pathol Clin Med. 2000;47:181-192.

10. Blount DG, Pritchard DI, Heaton PR. Age-related alterations to immune parameters in Labrador retriever dogs. Vet Immunol Immunopathol. 2005;108:399-407.

11. Meydani SN, Hayek MG, Wu D, et al. Vitamin E and immune response in aged dogs. In: Reinhart GA, Carey DP, editors. Recent Advances in Canine and Feline Nutrition. Wilmington: Orange Frazer Press; 2000;3:295-303.

12. Heaton PR, Blount DG, Devlin P, et al. Assessing age-related changes in peripheral blood leukocyte phenotypes in Labrador retriever dogs using flow cytometry. J Nutr. 2002;132:1655S-1657S.

13. Heaton PR, Blount DG, Mann SJ, et al. Assessing age-related changes in peripheral blood leukocyte phenotypes in domestic shorthaired cats using flow cytometry. $J$ Nutr. 2002;132:1607S-1609S.

14. Faldyna M, Levá L, Knötigová $\mathrm{P}$, Toman M. Lymphocyte subsets in peripheral blood of dogs - a flow cytometric study. Vet Immunol Immunopathol. 2001;82:23-37.

15. Reis AB, Carneiro CM, Carvalho MG, et al. Establishment of a microplate assay for flow cytometric assessment and it is use for the evaluation of age-related phenotypic changes in canine whole blood leukocytes. Vet Immunol Immunopathol. 2005;103:173-185.

16. Smith KA. Interleukin-2: inception, impact, and implications. Science. 1988;240:1169-1176.

17. Tapp PD, Siwak CT, Estrada J, et al. Size and reversal learning in the beagle dog as a measure of executive function and inhibitory control in ageing. Learn Mem. 2003;10:64-73.

18. Laflamme D. Development and validation of a body condition score system for dogs. Canine Pract. 1997;22:10-15.

19. Todo-Bom A, Mota-Pinto A, Alves V, Santos-Rosa M. Aging and asthma - changes in CD45RA, CD29 and CD95 T cells subsets. Allergol Immunopathol (Madr). 2012;40:14-19.

20. Provinciali M, Moresi R, Donnini A, Lisa RM. Reference values for CD4+ and CD8+ T lymphocytes with naïve or memory phenotype and their association with mortality in the elderly. Gerontology. 2009;55:314-321.

21. Stulnig T, Maczek C, Böck G, Majdic O, Wick G. Reference intervals for human peripheral blood lymphocyte subpopulations from 'healthy' young and aged subjects. Int Arch Allergy Immunol. 1995;108: 205-210.

22. Hedlund G, Dohlsten M, Ericsson PO, Sjögren HO. Rapid response to Con A by CD4+ CD45R- rat memory lymphocytes as compared to CD4+ CD45R+ lymphocytes. Cell Immunol. 1989;119:317-326. 
23. Sasama J, Vyas B, Vukmanovic-Stejic M, Kemeny DM. Effect of IL-4, IFN-gamma and IL-12 on cytokine production from human CD45RA and CD45RO CD4 T cell precursors. Int Arch Allergy Immunol. 1998; 117:255-262.

24. Lantz O, Grandjean I, Matzinger P, Di Santo JP. Gamma chain required for naïve CD4+ T cell survival but not for antigen proliferation. Nat Immunol. 2000;1:54-58.
25. Vivien L, Benoist C, Mathis D. T lymphocytes need IL-7 but not IL-4 or IL-6 to survive in vivo. Int Immunol. 2001;13:763-768.

26. Wang X, Rickert M, Garcia KC. Structure of the quaternary complex of interleukin-2 with its alpha, beta, and gammac receptors. Science. 2005;310:1159-1163

\section{Publish your work in this journal}

Veterinary Medicine: Research and Reports is an international, peer-reviewed, open access journal publishing original research, case reports, editorials, reviews and commentaries on all areas of veterinary medicine. The manuscript management system is completely online and includes a very quick and fair peer-review system.
Visit http://www.dovepress.com/testimonials.php to read real quotes from published authors.

Submit your manuscript here: http://www.dovepress.com/veterinary-medicine-research-and-reports-journal 